achieved in the best hands". This chapter as a whole, excellently written though it may be, fits oddly into the series. Much of it is devoted to discussion of the relative merits of institutional and domiciliary treatment and this surely is much more a medico-social question than a problem of chemotherapy.

The two chapters, one on "Cephalosporins" and the other on "Olivomycin, Mithramycin, Chromomycin: Three Related Cancerostatic Antibiotics", are perhaps the best models for collections of this sort. They deal most readably with limited topies, authoritatively enough for the expert while still maintaining interest for the general reader. To a slightly lesser extent, the samo is true of the very different chapter on "Systemic Control of Plant Nematodes". But of the chapter on "Purine and Pyrimidine Analogs" one can only" agroe with the authors themselves when they say that "To some extent ... readability has been sacrificed to logic. ..." This proves a severe disadvantage in a book that has been produced to be read.

Walter Davis

\section{Human Nutrition and Dietetics}

By Stanley Davidson and R. Passmore. Third edition. Pp. xii +864 . (Edinburgh and London: E. and $\mathrm{S}$. Livingstone, Ltd., 1966.) 95s. net.

Is bringing this invaluable text-book on human nutrition up to date the authors have revised all the sections and brought the bibliography up to 1965 to include most recent revisions of recommended allowances of nutrients and other such important material. Chapters on the composition of the body, appetite and satiety, proteins, fats, carbohydrates, poisons, various deficiency diseases and the population problem have been completely rewritten.

In Part IV of the book, which is concerned with diet and physiological stress, the chapter on nutrition and care of the aged is considerably revised and new statistical data are included as well as a brief comment on social aspects of the problems of the increasing numbers of aged members of the population. This is only one example of the way in which the text has been improved since the first edition in 1959. The book continues to be indispensable for all students and teachers in the field of nutrition and dietetics as it brings together in one volume the whole subject of food for man. It is written by medical authors but their language, style and approach are such as to be fully understood by both medical and non-medical readers. In fact, most of the text makes easy reading for the student or the layman. For those who need deeper knowledge of particular problems the references give proper leads into the relevant literature. References to recent reviews are especially useful and are given in many sections where only a brief treatment of a subject is indicated.

\section{A. M. Copring}

\section{Embryology of the Ovary and Testis}

Homo sapiens and Macaca mulatta. By Gertrude van Wagenen and Miriam E. Simpson. Pp. xvii +256. (New Haven and London: Yale University Press, 1965.) $56 s$.

Dr. Gortrude van Wagenen and Dr. Miriam E. Simpson have provided a valuable illustrated atlas which compares successive stages in the development of the ovary and testis in Man and the Rhesus monkey. Half the volume consists of plates of photo-micrographs, and for this reason alone its price is very moderate. Unfortunately the text is limited, both in scope and in the quality of the interpretation. The descriptions are on simple classical lines, and the study extends neither to an electron microscopic analysis of the kind with which students of gametogenesis are now becoming familiar, nor to a quantitative analysis of the stages of development which are described. Students will, none the less, find the book valuable, since even if it only confirms the classical picture of the development of the gonad, it provides useful background material with which those new to the subject will be able to orientate themselves in their more detailed studies.

\section{Insects in Southern Africa}

How to Control Them-a Handbook for Students, Health Officers, Gardeners, Farmers. By Bernard Smit. Pp. xiv + 399. (London and Cape Town: Oxford University Press, 1964.) 63s. net.

No text-book of economic entomology has been published in southern Africa since C. K. Brain produced his Insect Pests and their Control in South Africa in 1929. Since that time many new crops and new pests have been introduced; and the method of control, whether by cultural and biological means or by the use of modern insecticides, have been transformed. During the past forty years Dr. Bernard Smit has been engaged in economic entomology in South Africa and has indeed been responsible for many of the advances that have been made. It is most valuablo to have all this accumulated experience, much of which has hitherto been reported only in science bulletins and leaflets, brought together in book form. The book is wholly practical. Introductory matter is reduced to a minimum; no attempt is made to give more than the barest elements of insect anatomy, and insect physiology does not come into consideration. Clear and homely line drawings serve for identification. The insects are given their scientific, English and Africaans names; their life history and habits are clearly described; and measures of control are set out in a simple and effective style. The book is intended "for students, health officers, gardeners, farmers". It will fulfil this purpose admirably and can be warmly recommended. It may even find use outside South Africa.

V. B. WiggleswORTH

\section{Physical Properties of Martensite and Bainite}

(Report of the Proceedings of the joint conference organized by the British Iron and Steel Research Association and the Iron and Steel Institute, held at Scarborough, 10-12 May, 1965. Special Report 93.) Pp. 211. (London: The Iron and Steel Institute, 1965.) 1008.

THE physical properties of martensite and bainite are of great technological importance to the steel industry and also provide challenging topics of investigation for research workers in industry, the universities and research associations. This volume reports the proceedings of a conference attended by representatives from these different backgrounds and successfully reflects the diversity of interest in the crystallography, morphology and kinetics of these classes of phase transformations. Eighteen papers, which review the field and describe recent research, are included. These were circulated to participants before the meeting and this has helped to produce an informed discussion which provides a major and valuable section of the book. Although the martensite and bainite reactions in steels are given prominence, work on non-ferrous metals and alloys is also described, emphasizing the close relationship which exists between transformations in a wide range of materials. The most striking feature of the book is the wealth of experimental information on the internal structure of transformation products which has been revealed by thin foil eloctron microscopy in recent years. This should provide a stimulus to the further development of theories of martensite crystallography which have undergone only minor modifications in the past decade.

The papers and discussion are of a generally high standard and the presentation is attractive. In particular the Iron and Steel Institute are to be congratulated on publishing this report less than five months after the conference was held. A. G. Crocker 